\title{
Adsorption of Pu(IV) Polymer onto 304L Stainless Steel
}

by

M. G. Bronikowski

RECORDS ADMINISTRATION

Westinghouse Savannah River Company

Savannah River Site

Aiken, South Carolina 29808

M. L. Crowder

M. C. Thompson

DOE Contract No. DE-AC09-96SR18500

This paper was prepared in connection with work done under the above contract number with the U.S.

Department of Energy. By acceptance of this paper, the publisher and/or recipient acknowledges the U. S. Government's right to retain a nonexclusive, royalty-free license in and to any copyright covering this paper, along with the right to reproduce and to authorize others to reproduce all or part of the copyrighted paper. 
WSRC-TR-99-00210

Publication Date: June, 1999

\section{Adsorption of Pu(IV) Polymer onto 304L Stainless Steel(U)}

M. G. Bronikowski,

M. L. Crowder

M. C. Thompson 


\section{DISCLAIMER}

This report was prepared as an account of work sponsored by an agency of the United States Government. Neither the United States Government nor any agency thereof, nor any of their employees, makes any warranty, express or implied, or assumes any legal liability or responsibility for the accuracy, completeness, or usefulness of any information, apparatus, product, or process disclosed, or represents that its use would not infringe privately owned rights. Reference herein to any specific commercial product, process, or service by trade name, trademark, manufacturer, or otherwise does not necessarily constitute or imply its endorsement, recommendation, or favoring by the United States Government or any agency thereof. The views and opinions of authors expressed herein do not necessarily state or reflect those of the United States Government or any agency thereof.

This report has been reproduced directly from the best available copy.

Available to DOE and DOE contractors from the Office of Scientific and Technical Information, P.O. Box 62, Oak Ridge, TN 37831; prices available from (615) 576-8401.

Available to the public from the National Technical Information Service, U.S. Department of Commerce, 5285 Port Royal Road, Springfield, VA 22161. 


\section{Adsorption of Pu(IV) Polymer onto 304L Stainless Steel(U)}

M. G. Bronikowski,

M. L. Crowder

M. C. Thompson

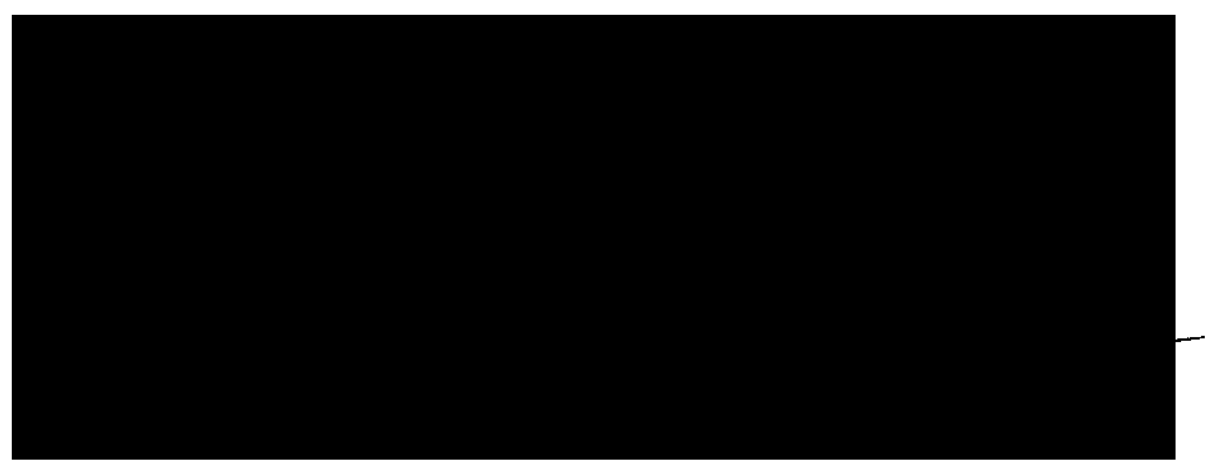




\section{Abstract}

The report, Technical Basis for Safe Operations with Pu-239 Polymer in NMS\&S Operating Facilities(F \& H Areas), (WSRC-TR-99-00008) ${ }^{\prime}$ was issued in an effort to upgrade the Authorization Basis (AB) for H Area facilities relative to nuclear criticality. At the time, insufficient data were found in the literature to quantify the adsorption of Pu polymer onto the surfaces of stainless steel tanks. Additional experimental or literature information on the adsorption of $\mathrm{Pu}(\mathrm{IV})$ polymer and its removal was deemed necessary to support the $\mathrm{H}$ Area $\mathrm{AB}$. The results obtained are also applicable to processing in $\mathrm{F}$ Area facilities.

Additional literature sources ${ }^{2-4}$ suggest that adsorption on the tank walls should not be a safety concern. The sources show that the amount of $\mathrm{Pu}$ polymer that adsorbs from a solution comes to a limiting amount in 5 to 7 days after which no additional Pu is adsorbed. Adsorption increases with Pu concentration and decreases with acid concentration. The adsorbed amounts are small varying from $0.5 \mu \mathrm{g} / \mathrm{cm}^{2}$ for a $0.5 \mathrm{~g} / 1$ $\mathrm{Pu} / 0.5 \mathrm{M} \mathrm{HNO}_{3}$ solution to $11 \mu \mathrm{g} / \mathrm{cm}^{2}$ for a $1-3 \mathrm{~g} / 1 \mathrm{Pu} / 0.1 \mathrm{M} \mathrm{HNO}_{3}$ solution. Additionally, acid concentrations greater than $0.1 \mathrm{M}$ will remove a percentage of adsorbed $\mathrm{Pu}$.

The experimental results have generally confirmed much of what has been reported in the literature. Specifically, adsorption onto stainless steel was found to increase with increased Pu concentration, and decreased acid concentration. The amount adsorbed was found to come to a limiting amount after 5 to 7 days. $\mathrm{Pu}$ adsorbed as polymer was found to be harder to remove than if it was adsorbed as $\mathrm{Pu}(\mathrm{IV})$. The amount of Pu adsorbed as polymer was found to be almost an order of magnitude more than that from a similar concentration $\mathrm{Pu}(\mathrm{IV})$ solution. Unlike the literature, only a slight increase in adsorption values was found when the steel surface was removed, dried, and replaced in the Pu solution. The amount of $\mathrm{Pu}$ as polymer which would adsorb onto the surface of a $14,000 \mathrm{~L}$ tank was estimated to be less than 10 grams and thus was not a safety concern. 
Table of Contents

Introduction 1

$\begin{array}{ll}\text { Literature } & 1\end{array}$

Experimental

Results 5

$\begin{array}{ll}\text { Discussion } & 8\end{array}$

$\begin{array}{lc}\text { Adsorption } & 8\end{array}$

$\begin{array}{lr}\text { Buildup } & \mathbf{1 0}\end{array}$

Conclusions 11

$\begin{array}{lr}\text { References } & 12\end{array}$

$\begin{array}{ll}\text { Appendix } & 13\end{array}$ 


\section{List of Figures}

Figure 1. $\mathrm{Pu}(\mathrm{IV})$ adsorption on stainless steel from $0.5 \mathrm{M} \mathrm{HNO}_{3}$ solutions with $\mathrm{Pu}$ concentrations of; 1) $\left.\left.5 \times 10^{-3} \mathrm{~g} / \mathrm{L}, 2\right) 5 \times 10^{-2} \mathrm{~g} / \mathrm{L}, 3\right) 2 \times 10^{-1} \mathrm{~g} / \mathrm{L}$, and 4) $5 \times 10^{-1} \mathrm{~g} / \mathrm{L}^{2}$

Figure 2. Adsorption of $\mathrm{Pu}(\mathrm{IV})$ on polished platinum in percent $(\mathrm{K} \cdot 100){ }^{3}$

Figure 3. Lego plots of the adsorption of Pu determined on 304L stainless steel in $\mu \mathrm{g} / \mathrm{cm}^{2}$. 6

Figure 4. Lego plots of the adsorption of Pu determined on 304L stainless steel in $\mu \mathrm{g} / \mathrm{cm}^{2}$ including additional data from literature.,

Figure 5. Pu adsorption on 304L stainless steel in $\mu \mathrm{g} / \mathrm{cm}^{2}$. 


\section{List of Tables}

Table 1. Determined values of adsorption from experiment 1 started 2/9/99.

Table 2. Determined values of adsorption from experiment 2 started 3/3/99.

Table 3. Determined values of adsorption from experiment 3 started 4/6/99.

Table 4. Determined values of adsorption from experiment 4 started 4/15/99.

Table 5. Determined values of adsorption from experiment 5 started 4/23/99.

Table 6. Determined values of adsorption from experiment 6 started 5/4/99. 


\section{Introduction}

The report, WSRC-TR-99-00008 ${ }^{1}$, was issued in response to the question of whether low acid solutions or water could be safely added to stainless steel tanks that contain plutonium. The report pointed out that such an addition should be avoided as it would produce plutonium polymer, which can adhere to surfaces and would be difficult to remove. As accidental additions are possible, how much polymer will adsorb and if it could be removed are important issues from a safety standpoint. At the time of writing WSRC-TR-99$00008^{\prime}$, insufficient data were found in the literature to quantify the adsorption of $\mathrm{Pu}$ polymer onto the surfaces of the stainless steel tanks. Only a single reference ${ }^{5}$ for $\mathrm{Pu}$ adsorption to steel was found. The values determined using a solution of $1-3 \mathrm{~g} / 1 \mathrm{Pu}$ in $0.1 \mathrm{M}$ acid were $4 \mu \mathrm{g} / \mathrm{cm}^{2}$ on polished steel and $11 \mu \mathrm{g} / \mathrm{cm}^{2}$ on unpolished steel. This document reports on the additional literature sources found and experimental work done on the adsorption of $\mathrm{Pu}(\mathrm{IV})$ polymer and its removal as deemed necessary to support the H Area AB.

\section{Literature}

Three literature sources on $\mathrm{Pu}$ adsorption were found, ${ }^{2-4}$ since WSRC-TR-99-00008 ${ }^{1}$ was issued. Two of

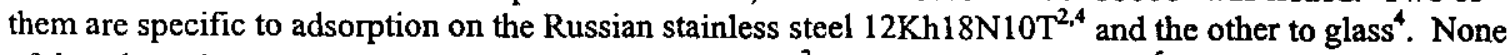
of the adsorption amounts were greater than the $4 \mu \mathrm{g} / \mathrm{cm}^{2}$ value previously found. ${ }^{5}$ The additional reported values did, however, elucidate the large variance in adsorption values reported for stainless steel, platinum, and glass. $^{2-8}$ The adsorption values determined on a specific surface were vastly different because Pu adsorption is an equilibrium process dependent on both acid and $\mathrm{Pu}$ concentration.

The important trends of $\mathrm{Pu}$ adsorption are explained by the adsorption data on stainless steel of Sokhina et al., ${ }^{2}$ in Figure 1. The most obvious trend is that adsorption increases with $\mathrm{Pu}$ concentration from 0.05 $\mu \mathrm{g} / \mathrm{cm}^{2}$ to $0.5 \mu \mathrm{g} / \mathrm{cm}^{2}$ as the $\mathrm{Pu}(\mathrm{IV})$ concentration increases from $5 \times 10^{-3} \mathrm{~g} / \mathrm{l}$ to $0.5 \mathrm{~g} / \mathrm{l}$. The next important trend is that the adsorption takes 5 to 7 days to come to equilibrium. Solutions at the same acidity with a higher concentration of $\mathrm{Pu}$ were found to take longer to come to equilibrium. A similar plot was made which shows the adsorption of $0.05 \mathrm{~g} / \mathrm{Pu}$ as the acid concentration varies from $0.1 \mathrm{M}$ to $3 \mathrm{M}$. The equilibrium rate was found to be dependent on acid concentration with the lowest concentration taking 8 days to reach equilibrium. This trend is the same as described by Samartseva ${ }^{6}$ for $1.2 \times 10^{-6} \mathrm{~g} / 1 \mathrm{Pu}$ adsorption on glass where equilibrium took 1 hour at $\mathrm{pH} 1.3,2-3$ hours at $\mathrm{pH} 2.7$ and 5-6 hours at $\mathrm{pH} 8$.

The increase in $\mathrm{Pu}$ (IV) adsorption with decrease in acidity was found to be due to hydrolyzed $\mathrm{Pu}$ forms or polymer. $^{3-6}$ Adsorption on stainless steel and glass followed the decreasing order of

$$
\mathrm{Pu} \text { polymer } \gg \mathrm{Pu}(\mathrm{IV})>\mathrm{Pu}(\mathrm{VI})>\mathrm{Pu}(\mathrm{III}) \text {. }
$$

In fact, the difference between $\mathrm{Pu}$ polymer and $\mathrm{Pu}(\mathrm{IV}) \mathrm{can}$ be as large as an order of magnitude for the same $\mathrm{Pu}$ and acid concentrations and contact time. ${ }^{4}$ The adsorption order can be explained by the increased effective positive charge of the $\mathrm{Pu}$ polymer and $\mathrm{Pu}(\mathrm{IV})$ species being attracted more strongly to the negatively charged steel and glass surfaces than $\mathrm{Pu}(\mathrm{VI})$ and $\mathrm{Pu}(\mathrm{III})$. Whether fresh, initially produced polymer, or aged polymer adsorbs more is still left to debate. Ichikawa ${ }^{11}$ found aged Pu polymer, [Pu]= $4.1 \times 10^{-3} \mathrm{~g} / \mathrm{L}$, in $0.1 \mathrm{M} \mathrm{HNO}_{3}$ adsorbed on polyethylene centrifuge tubes $20 \%$ more than fresh Pu polymer. However, adsorption on glass or platinum with increasing $\mathrm{pH}$ suggests that aged polymer adsorbs less than fresh polymer because the aged polymer has less positive charge and larger size. All of the literature data on stainless steel was taken with fresh $\mathrm{Pu}$ polymer which is what would be expected to be produced if water was inadvertently added to a process tank containing $\mathrm{Pu}(\mathrm{IV})$. 


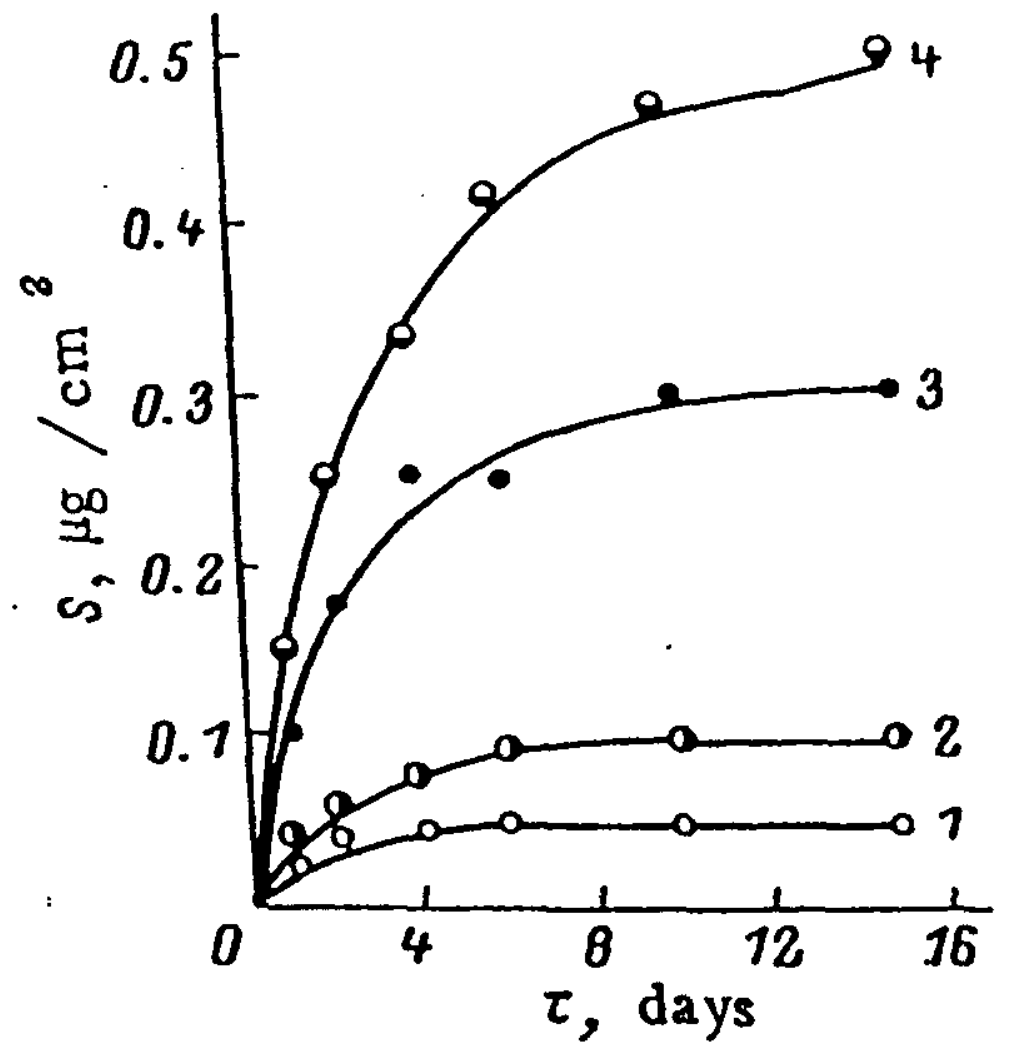

Figure 1. $\mathrm{Pu}(\mathrm{IV})$ adsorption on stainless steel from $0.5 \mathrm{M} \mathrm{HNO}_{3}$ solutions with $\mathrm{Pu}$ concentrations of 1) $\left.\left.5 \times 10^{-3} \mathrm{~g} / \mathrm{L}, 2\right) 5 \times 10^{-2} \mathrm{~g} / \mathrm{L}, 3\right) 2 \times 10^{-1} \mathrm{~g} / \mathrm{L}$, and 4) $5 \times 10^{-1} \mathrm{~g} / \mathrm{L}$. $^{2}$ (Published with the permission of Plenum Publishing Corp.)

The adsorption behavior of $\mathrm{Pu}$ on stainless steel as the $\mathrm{pH}$ changes can be expected to be similar to its adsorption on platinum ${ }^{6}$ as seen in Figure 2. The trends depicted are the same as those for $\mathrm{Pu}$ adsorption on glass and quartz. As the $\mathrm{pH}$ increases to almost 1 , or $0.1 \mathrm{M} \mathrm{HNO}_{3}$ acid, $\mathrm{Pu}$ adsorption begins to increase until a $\mathrm{pH}$ of 2 , where it reaches $100 \%$. As the $\mathrm{pH}$ becomes higher, the percent adsorption decreases. This decrease begins at a pH which is dependent on other components in the solution. Pure Pu solutions begin to show decreasing adsorption on platinum with pHs higher than 4. Pu solutions containing $\mathrm{Fe}\left(\mathrm{NO}_{3}\right)_{3}$, $\mathrm{Th}\left(\mathrm{NO}_{3}\right)_{4}$ and $\mathrm{Zr}\left(\mathrm{NO}_{3}\right)_{4}$ have been found to decrease $\mathrm{Pu}$ adsorption on platinum substantially by $\mathrm{pH} 4$.

The percent adsorbed, although used extensively in earlier work for Pu adsorption on platinum, glass, and quartz, ${ }^{3,6,8,9}$ is misleading unless it is tied to a plutonium concentration. For example, adsoprtion on stainless steel was found to be $20 \%$ for a $10^{-7} \mathrm{M}$ Pu solution and only $2 \%$ for a $10^{-5} \mathrm{M}$ Pu solution, suggesting that more $\mathrm{Pu}$ is adsorbed from the first solution. In reality, for the same volume of solution, $2 \%$ of the $10^{-5} \mathrm{M}$ solution will deposit ten times more Pu onto the steel. Less confusion occurs when $\mu \mathrm{g} / \mathrm{cm}^{2}$ is used to compare adsorption amounts, especially if different solution concentrations are to be compared. 


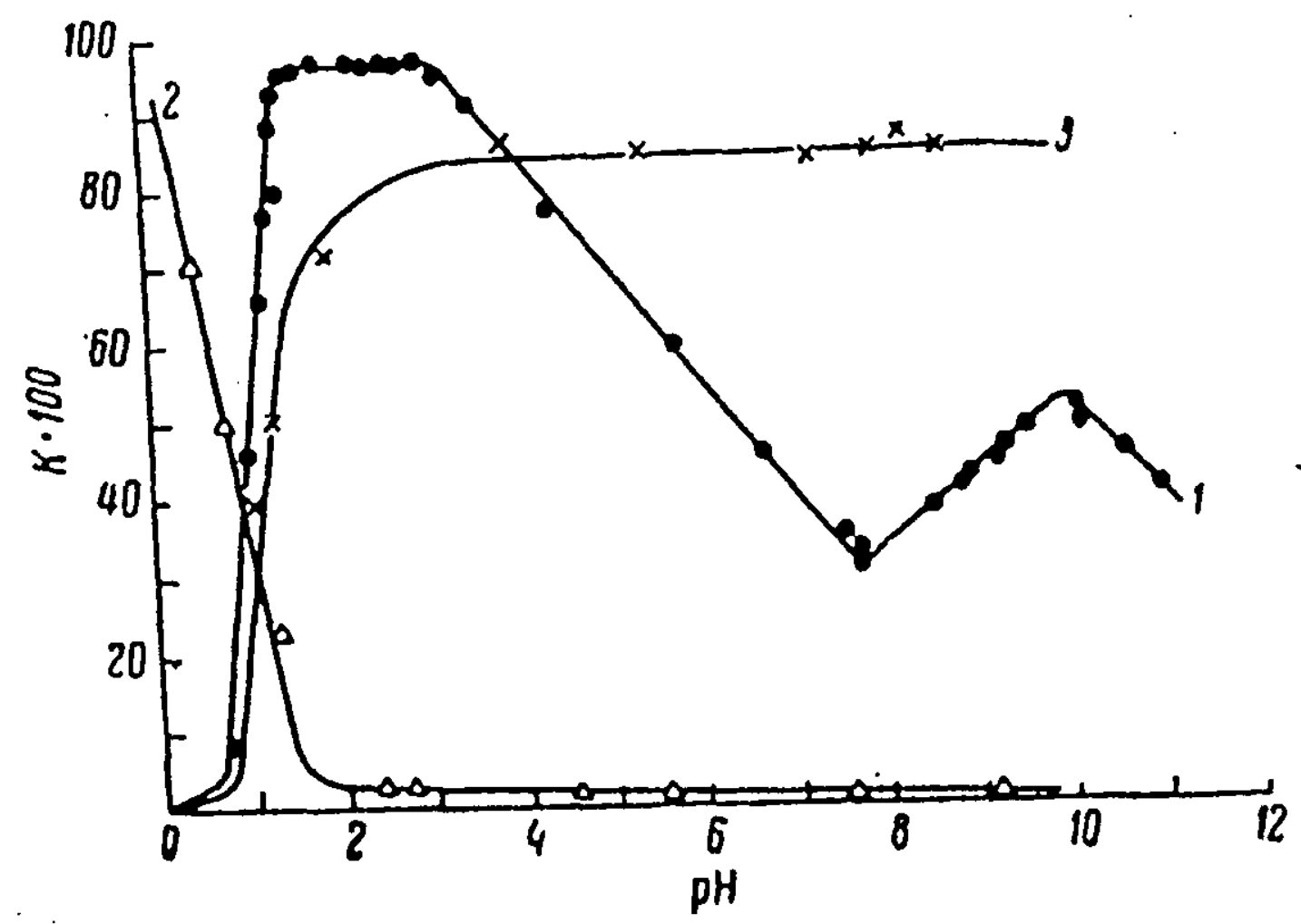

Figure 2. Adsorption of $\mathrm{Pu}(\mathrm{IV})$ on polished platinum in percent $(\mathrm{K} \cdot 100) .^{3}$ Lines represented are:1) the percent $\mathrm{Pu}$ adsorbed from a solution at the given $\mathrm{pH}, 2)$ the percent $\mathrm{Pu}$ desorbed with a solution of the given $\mathrm{pH}$, and 3) the percent $\mathrm{Pu}$ desorbed with $0.5 \mathrm{M} \mathrm{HNO}_{3}$ which was previously adsorbed at the given $\mathrm{pH}$.

The desorption behavior of $\mathrm{Pu}$ from stainless steel, as the $\mathrm{pH}$ of the desorbing solution increases, can be expected to be similar to its desorption from platinum and glass. As seen in Figure 2 for a platinum surface, the percent of $\mathrm{Pu}$ removed decreases rapidly until $\mathrm{pH} 2$ where the percent removal remains $5 \%$ or less for desorbing solutions of higher $\mathrm{pHs}$. With a glass surface the $5 \%$ or less desorption begins at a $\mathrm{pH}$ higher than 4. When the more acidic solution of $0.5 \mathrm{M} \mathrm{HNO}_{3}$ is used to desorb Pu from platinum, $90 \%$ of the $\mathrm{Pu}$ is removed. This suggests an irreversible adsorption process and the possibility of $\mathrm{Pu}$ buildup on a surface with subsequent use. However, Belloni et al., found that cerium, an element used as a Pu analogue, and promethium, a lanthanide which should react similarly to $\mathrm{Pu}$, are removed quantitatively from platinum or polyvinyl chloride at high acid concentrations. ${ }^{10}$ Ruthenium, which has multiple oxidation states in solution like $\mathrm{Pu}$, does behave irreversibly, having slow and incomplete desorption but rapid adsorption. The latter irreversible case was found, for low acid and $\mathrm{Pu}$ concentration solutions, which have increased $\mathrm{Pu}$ deposition on platinum and stainless steel with subsequent solution contact. ${ }^{2,8}$ Acid concentrations greater than $0.5 \mathrm{M}$ at $95^{\circ} \mathrm{C}$ remove $\mathrm{Pu}$ from stainless steel reversibly. This removal becomes irreversible at lower temperatures where an equilibrium saturation amount is deposited which is slightly higher than if the solution contacted the steel continuously. At less than $0.5 \mathrm{M} \mathrm{HNO}_{3}$ and higher temperatures $\left(60^{\circ} \mathrm{C}\right.$ and $95^{\circ} \mathrm{C}$ ), Pu irreversibly built up to $4 \mu \mathrm{g} / \mathrm{cm}^{2}$ on stainless steel. ${ }^{2}$ 
Experiments were run to determine the adsorption $\left(\mu \mathrm{g} / \mathrm{cm}^{2}\right)$ of plutonium polymer onto $304 \mathrm{~L}$ stainless steel, which is the steel used in $\mathrm{H}$ Canyon and HB Line tanks. Pu(IV) solutions were diluted with various acid concentrations in the experiments to get realistic adsorption values, as would be found in $\mathrm{H}$ Canyon and HB Line tanks if a low level acid dilution occurred. The results were expected to complement the recently found adsorption information from the literature for Russian stainless steel. The important effects on Pu adsorption caused by the concentration of Pu polymer, the time the polymer solution is in contact with the steel, and occasional drying of the steel between exposures to Pu polymer solution were studied.

\section{Experimental}

The adsorption of Pu was studied on 304L stainless steel rods immersed in solutions which ranged in concentration from $0.191 \mathrm{~g} / 1$ to $6.56 \times 10^{-2} \mathrm{~g} / 1 \mathrm{Pu}$ and $4.4 \times 10^{-3} \mathrm{M}$ to $5.0 \mathrm{M} \mathrm{HNO}_{3}$. The experiments were carried out in $125 \mathrm{~mL}$ stainless steel beakers. A glass cover, which would hold four, 4-inch long by $1 / 4$-inch diameter, 304L stainless steel rods was placed over each beaker. The stainless steel rods had a hard rubber grommet inserted 2.5 inches from the end so that they would be suspended above the bottom of the beaker. This configuration produced an immersed stainless steel rod surface area of $0.556 \pm 0.015 \mathrm{~cm}^{2}$ when $30 \mathrm{ml}$ of solution were added to the beaker. The beakers and rods were etched with $40 \mathrm{ml}$ of $8.0 \mathrm{M} \mathrm{HNO}_{3} / 0.05 \mathrm{M}$ $\mathrm{KF}$ for $24 \mathrm{hrs}$ to clean the metal surfaces prior to use.

Adsorption experiments were conducted as follows. In a radiological hood, $30 \mathrm{ml}$ of water or $\mathrm{HNO}_{3}$ solution were added to a beaker followed by spiking with $0.1-0.3 \mathrm{ml}$ of a concentrated $(\sim 20 \mathrm{~g} / \mathrm{l}) \mathrm{Pu}$ (IV) solution. In the experiments run with $0.154 \mathrm{~g} / \mathrm{l} \mathrm{Pu}(\mathrm{IV}), 30 \mathrm{ml}$ of a previously prepared solution was added to the beaker. A glass cover, holding four steel rods, was then placed on the beaker. The whole beaker assembly was covered with a two liter polypropylene bottle to decrease evaporation of the Pu solution during the experiment. Individual rods were removed from the solution after 1 to 8 days of immersion. After a rod was removed, it was rinsed with $0.1 \mathrm{M} \mathrm{HNO}_{3}$ to remove any residual solution adhering to the rod. The adsorbed $\mathrm{Pu}$ was removed from the rod by etching in $5 \mathrm{ml}$ of $8.0 \mathrm{M} \mathrm{HNO}_{3} / 0.05 \mathrm{M} \mathrm{KF}$ for 10 minutes. The rinse and etch steps were repeated a second time to make sure that all of the Pu was removed. The two 5-ml etch solutions were then individually analyzed for plutonium content by liquid scintillation counting.

Adsorption experiments were also conducted where rods were non-continuously immersed. The method described above was used except that the rods were removed, allowed to dry for at least one hour, and returned to the solution. The acid and $\mathrm{Pu}$ concentrations used were the same in these experiments as in the constant immersion experiments in order to compare adsorption values.

The initial experiments varied slightly from above. In the first experiment, no polypropylene bottle was used to cover the experiment. As a result, considerable evaporation of the Pu solution occurred. The covering of the beaker assembly with the bottle as well as the covering of the holes in the glass cover with thin rubber disks eliminated the evaporation problem. In the first two experiments the adsorbed Pu was removed by etching the rods for 5 minutes with $5 \mathrm{ml}$ of hot concentrated nitric acid. Sample vials with 5 $\mathrm{ml}$ of concentrated nitric acid were placed in a beaker acting as a water bath on a hot plate in the hood. Rods to be etched were placed in the sample vials for 5 minutes when the water bath began to bubble. This method was abandoned after the second experiment when a first etch left $7 \%$ of the adsorbed Pu on a rod. The method of etching in $5 \mathrm{ml}$ of $8.0 \mathrm{M} \mathrm{HNO}_{3} / 0.05 \mathrm{M} \mathrm{KF}$ for 10 minutes works as well or better and was much simpler to perform. 


\section{Results}

The results of the adsorption experiments are given in Tables 1- 6 in the Appendix. ${ }^{12}$ Both the raw $\mathrm{dpm} / \mathrm{ml}$ alpha data for the $5-\mathrm{ml}$ etch solutions and the calculated adsorption values in $\mu \mathrm{g} / \mathrm{cm}^{2}$ are tabulated. In discussing the resulting data, low acid will be defined as an acid concentration below $0.22 \mathrm{M} \mathrm{HNO}_{3}$ where polymerization may be expected to start at $6 \mathrm{~g} / \mathrm{L}$. High acid is greater than $0.22 \mathrm{M}$. Although the data at low acid concentrations are not nearly as consistent as the data at high acid concentrations, definite trends in the data can be seen. Specifically, experiments run at low acid concentrations where Pu polymer exists have greater adsorption by at least an order of magnitude than those run at higher acid concentrations. For example, adsorption was $3.0 \mu \mathrm{g} / \mathrm{cm}^{2}$ for a $0.131 \mathrm{~g} / 1 \mathrm{Pu}$ solution at $8.9 \times 10^{-3} \mathrm{M} \mathrm{HNO}_{3}$ when polymer is expected and $0.042 \mu \mathrm{g} / \mathrm{cm}^{2}$ at $0.36 \mathrm{M} \mathrm{HNO}_{3}$ when it is not. The highest adsorption, after a week, was found to be $7.0 \mu \mathrm{g} / \mathrm{cm}^{2}$ for a $0.131 \mathrm{~g} / 1 \mathrm{Pu}$ solution at $8.9 \times 10^{-3} \mathrm{M} \mathrm{HNO}_{3}$ for the case where a rod was removed, dried, and replaced daily. The highest non-equilibrium values were from low acid levels . where Pu polymer is expected to exist and ranged anywhere from $1-15 \mu \mathrm{g} / \mathrm{cm}^{2}$. Most of these were in the $5-7 \mu \mathrm{g} / \mathrm{cm}^{2}$ range.

In general, it was found that adsorption increases with time of immersion and concentration of $\mathrm{Pu}$. The adsorption does not increase indefinitely, but it attains an equilibrium value which is dependent on acid and $\mathrm{Pu}$ concentration. The time it takes to come to equilibrium varies with $\mathrm{Pu}$ and acid concentration. In the experiments performed, it took 5 to 7 days to reach equilibrium. For example in $0.131 \mathrm{~g} / 1 \mathrm{Pu}$ at $0.21 \mathrm{M}$ $\mathrm{HNO}_{3}$ adsorption increases from $0.032 \mu \mathrm{g} / \mathrm{cm}^{2}$ to $0.078 \mu \mathrm{g} / \mathrm{cm}^{2}$ in a week. In the polymer case, this equilibrium trend is not as distinct, as seen by the adsorption values of $1.3 \mu \mathrm{g} / \mathrm{cm}^{2}$ (after 1 day), $2.3 \mu \mathrm{g} / \mathrm{cm}^{2}$ (5 days), $3.8 \mu \mathrm{g} / \mathrm{cm}^{2}$ (7 days), and $2.9 \mu \mathrm{g} / \mathrm{cm}^{2}$ (8 days) for $0.19 \mathrm{~g} / \mathrm{l} \mathrm{Pu}$ in $0.015 \mathrm{M}$ nitric acid.

Alternately, adsorption of $\mathrm{Pu}$ did decrease from the amount initially adsorbed to attain an equilibrium value if acid concentrations were high. When $5 \mathrm{M} \mathrm{HNO}_{3}$ was used, adsorption of $\mathrm{Pu}$ from a $0.131 \mathrm{~g} / 1 \mathrm{Pu}$ solution dropped from an initial $0.014 \mu \mathrm{g} / \mathrm{cm}^{2}$ after a day to $0.006 \mu \mathrm{g} / \mathrm{cm}^{2}$ after a week. The same decrease was seen for a $0.191 \mathrm{~g} / \mathrm{l} \mathrm{Pu}$ solution where adsorption went from $1 \mu \mathrm{g} / \mathrm{cm}^{2}$ to the limit of detection for the measurement. Thus, adsorbed $\mathrm{Pu}$ will be removed from stainless steel until an equilibrium value is obtained. The initial adsorption was greater initially if an oxidized layer was present, as in Ockenden and Welch's non-polished results. ${ }^{5}$ Such conditions existed for the first two experiments where the rods were left for a day or so before use. In these experiments with the same solution $\left(0.154 \mathrm{~g} / \mathrm{Pu} / 0.69 \mathrm{M} \mathrm{HNO}_{3}\right)$, $\mathrm{Pu}$ adsorption on oxidized stainless steel was $1.8 \mu \mathrm{g} / \mathrm{cm}^{2}$ and $0.96 \mu \mathrm{g} / \mathrm{cm}^{2}$, while adsorption on the nonoxidized stainless steel was only $0.005 \mu \mathrm{g} / \mathrm{cm}^{2}$.

Adsorption was found to be greater when a rod was removed, let dry, and replaced. In all cases where a rod was lifted out of a solution until it dried and then replaced, more Pu was adsorbed after 7 days than the analogous continuous immersion. It is interesting to note that on the first day the amount adsorbed for the lifted case was always less than the continuous immersion case. After the 3rd day the lifted and unlifted adsorption values were about the same. This result can be attributed to the fact that the lifted rods were in the Pu solution a smaller percentage of the time as compared to continuous immersion. Understandably, when the percentage immersion time difference becomes much smaller after the 7 th day, adsorption on the lifted rods is greater.

Finally, $\mathrm{Pu}$ adsorbed as polymer was found to be harder to remove than $\mathrm{Pu}$ adsorbed as $\mathrm{Pu}(\mathrm{IV}) . \mathrm{Pu}(\mathrm{IV})$ in $0.69 \mathrm{M}$ acid was deposited in the first experiment due to the evaporation of the initial solution. A visible absorption spectra taken of the $3 \mathrm{ml}$ of solution left showed that only Pu(IV) and a little P(III) were present while the solution evaporated. Removal of the Pu from the rod was similar to the rest of the experiments which were at high acidity. That is, the Pu was almost totally removed by the first etching. This result is 


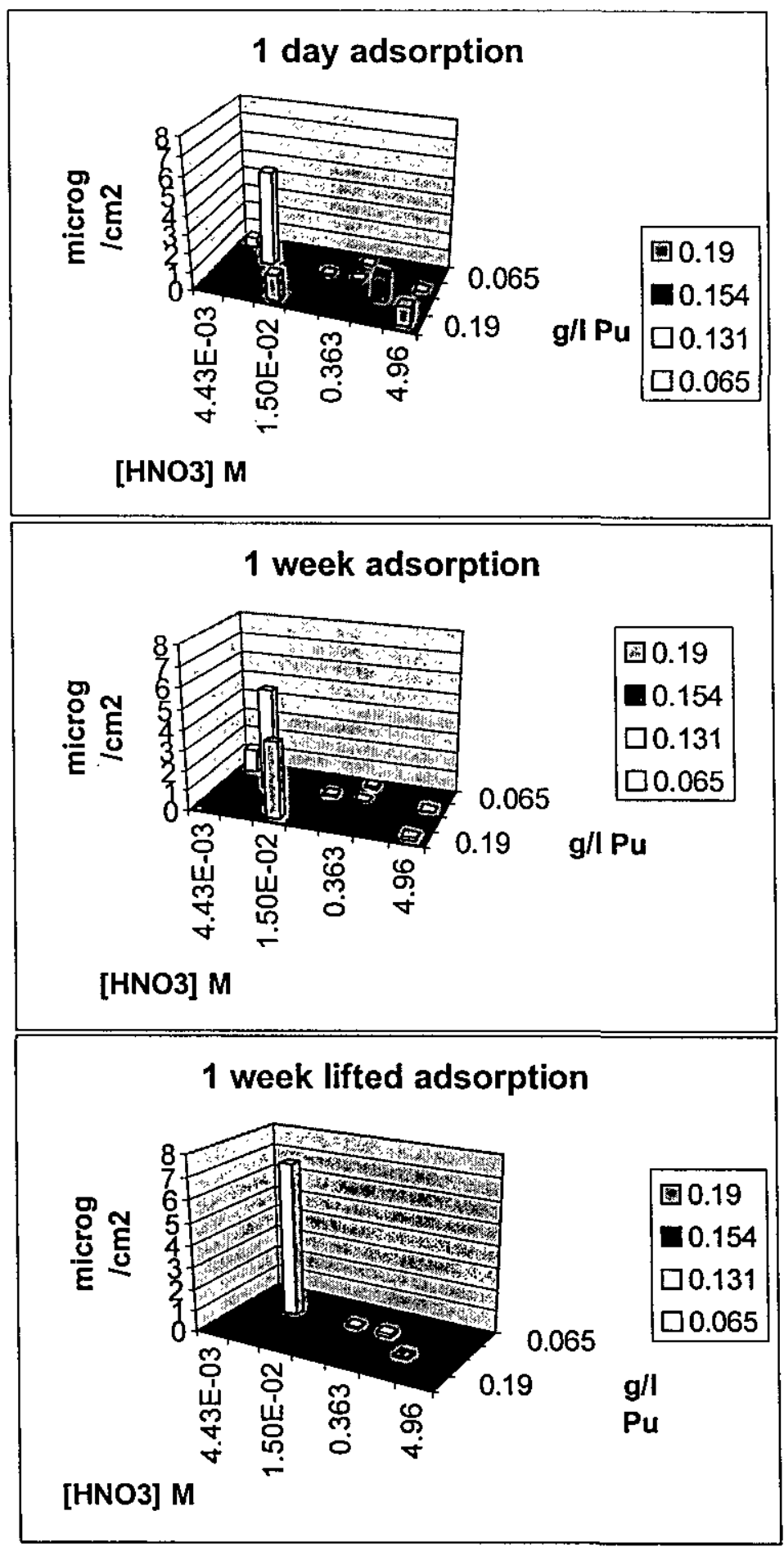

Figure 3. Lego plots of the adsorption of Pu determined on 304L stainless steel in $\mu \mathrm{g} / \mathrm{cm}^{2}$. Three cases are shown; an initial adsorption after one day of immersion, the equilibrium adsorption after one week of immersion, and adsorption from intermittent immersion in a Pu solution. 

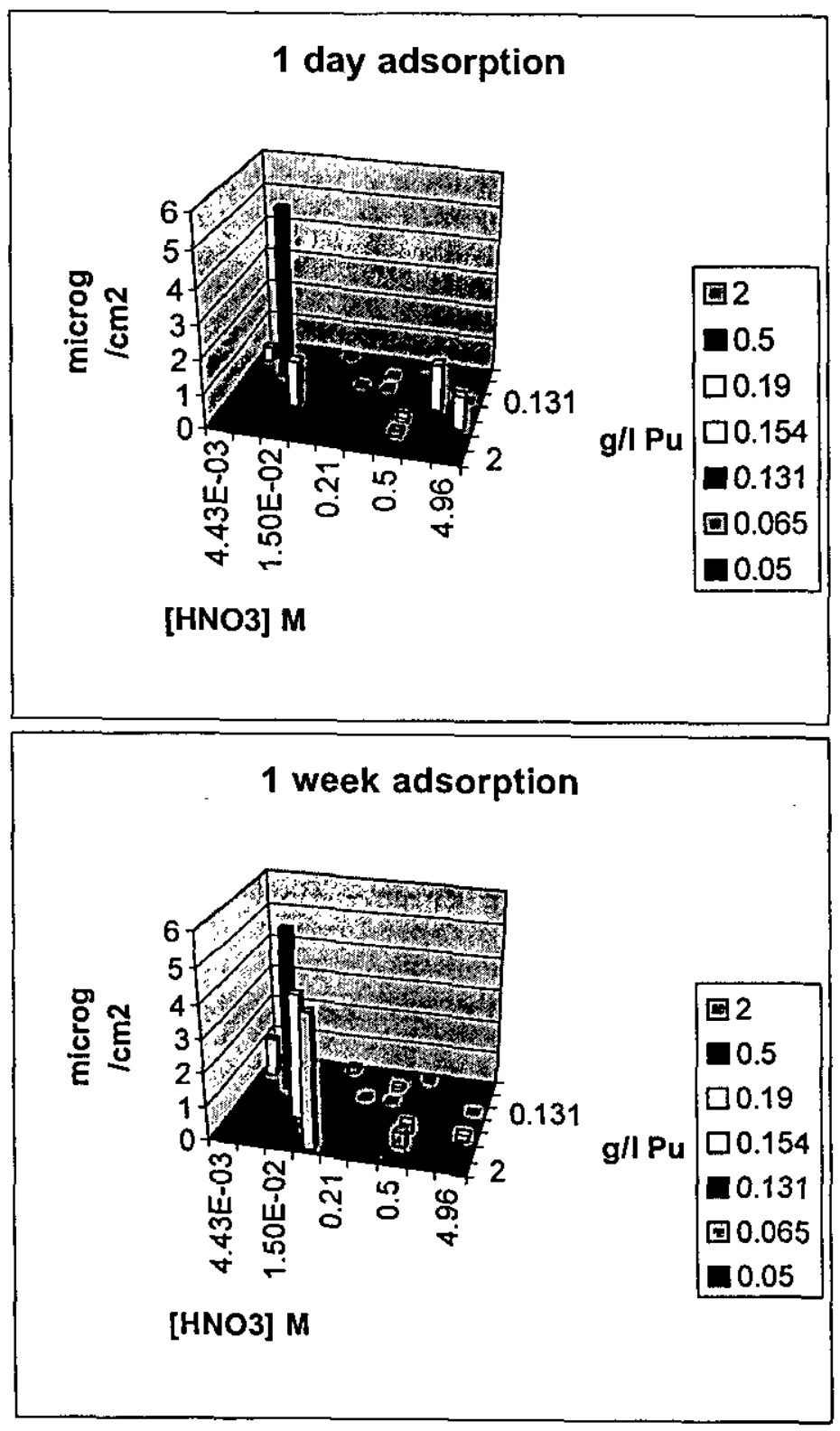

Figure 4. Lego plots of the adsorption of Pu determined on 304L, stainless steel in $\mu \mathrm{g} / \mathrm{cm}^{2}$ including additional data from literature. 
unlike the low acid experiments, where polymer was expected, which were found to have far more $\mathrm{Pu}$ removed by a second etching than in the high acidity case.

The experimental results are shown in the three LEGO plots of Figure 3 so that the trends can be more easily seen. The adsorption on the first day and that of the seventh day when equilibrium is attained are plotted as well as the non-continuous immersion, or lifted, results. One immediately sees that at low acid concentrations $\mathrm{Pu}$ adsorption is larger than at the higher acid concentration due to the existence of polymer. The difference between the initial adsorption and the equilibrium adsorption changes in the same manner. For example, the $0.191 \mathrm{~g} / \mathrm{l}$ Pu solutions have about the same adsorption on the first day, but days later at equilibrium, the low acid $\mathrm{Pu}$ adsorption has risen while that of the high acid solution has decreased. The other increased adsorption is also in the low acid polymer region for $0.065 \mathrm{~g} / 1$ solution. The noncontinuous adsorption plot at equilibrium has the same acid concentration cutoff. However, the increased adsorption in the high acid region is slight. Increased adsorption in the low acid region is greater if the average adsorption at $0.131 \mathrm{~g} / 1 \mathrm{Pu}$ of $5.0 \mu \mathrm{g} / \mathrm{cm}^{2}$ (average of $3.0 \mu \mathrm{g} / \mathrm{cm}^{2}$ and $7.0 \mu \mathrm{g} / \mathrm{cm}^{2}$ ) is compared to the single lifted adsorption value of $7.1 \mu \mathrm{g} / \mathrm{cm}^{2}$.

\section{Discussion}

The experimental results are plotted in Figure 4 with those gleaned from literature. The additional data from Ockenden and Welch, ${ }^{5}$ and Sokhina et al., ${ }^{2}$ fit the experimental data well even though Sokhina et al., used Russian stainless steel instead of 304L. This fit suggests that the trends seen for stainless steel in the literature are reliable to use for the tanks in the canyons and lines at the Savannah River Site. Some adsorption values from literature were not included in Figure 4 because conditions in which they were determined were not given, or equilibration times were not listed, or the $\mathrm{Pu}$ concentrations used were far too small to correspond to industrial scale operations. One important value that is not included in the plot is the $11 \mu \mathrm{g} / \mathrm{cm}^{2}$ unpolished stainless steel value from Ockenden and Welch. ${ }^{5}$ While this value is reliable, it is not an etched or polished steel value as the rest of the data are.

\section{Adsorption}

None of the equilibrium adsorption data exceeds the $11 \mu \mathrm{g} / \mathrm{cm}^{2}$ value determined by Ockenden and Welch, ${ }^{5}$ suggesting that this value can be used as an upper limit for adsorption of $\mathrm{Pu}$ polymer on stainless steel. In our experiments a few non-equilibrium adsorption values were found which were larger, but most of these were from the solution that evaporated in the first experiments. The only value obtained, without evaporation, above $11 \mu \mathrm{g} / \mathrm{cm}^{2}$ was $15 \mu \mathrm{g} / \mathrm{cm}^{2}$ for $0.131 \mathrm{~g} / 1 \mathrm{Pu}$ in $8.9 \times 10^{-3} \mathrm{M}$ acid. But this value is highly suspect since it is so uncharacteristically large compared to the other data within the experiment that it may have been due to not rinsing the rod well enough. Most of the absorption values determined when polymer was produced are between $2-7 \mu \mathrm{g} / \mathrm{cm}^{2}$. The literature value for polished steel of $4 \mu \mathrm{g} / \mathrm{cm}^{2}$ is in this range. Since a mono layer of $\mathrm{Pu}$ on stainless steel corresponds to $3.9 \mu \mathrm{g} / \mathrm{cm}^{2}$, as calculated using an estimated diameter of $1 \AA$ for $\mathrm{Pu}(\mathrm{IV}), 2-7 \mu \mathrm{g} / \mathrm{cm}^{2}$ is an extremely small amount of Pu which adsorbs. Even the $\mathrm{Pu}$ (IV) which was evaporated to $130 \mu \mathrm{g} / \mathrm{cm}^{2}, \sim 30$ monolayers worth, could not be seen by the naked eye and thus would not be expected to flake off the stainless steel.

The experimental and literature data at equilibrium definitely show that adsorption is greater for Pu solutions where polymer is expected to be present. This is shown in Figure 5, where Pu adsorption values determined on stainless steel are grouped into adsorption greater than $1 \mu \mathrm{g} / \mathrm{cm}^{2}$, from $1 \mu \mathrm{g} / \mathrm{cm}^{2}-0.5$ $\mu \mathrm{g} / \mathrm{cm}^{2}$, and less than $0.1 \mu \mathrm{g} / \mathrm{cm}^{2}$. The line, previously calculated in WSRC-TR-99-00008', corresponding to $2 \%$ polymer formation after four days is also included on the graph. All values of adsorption 


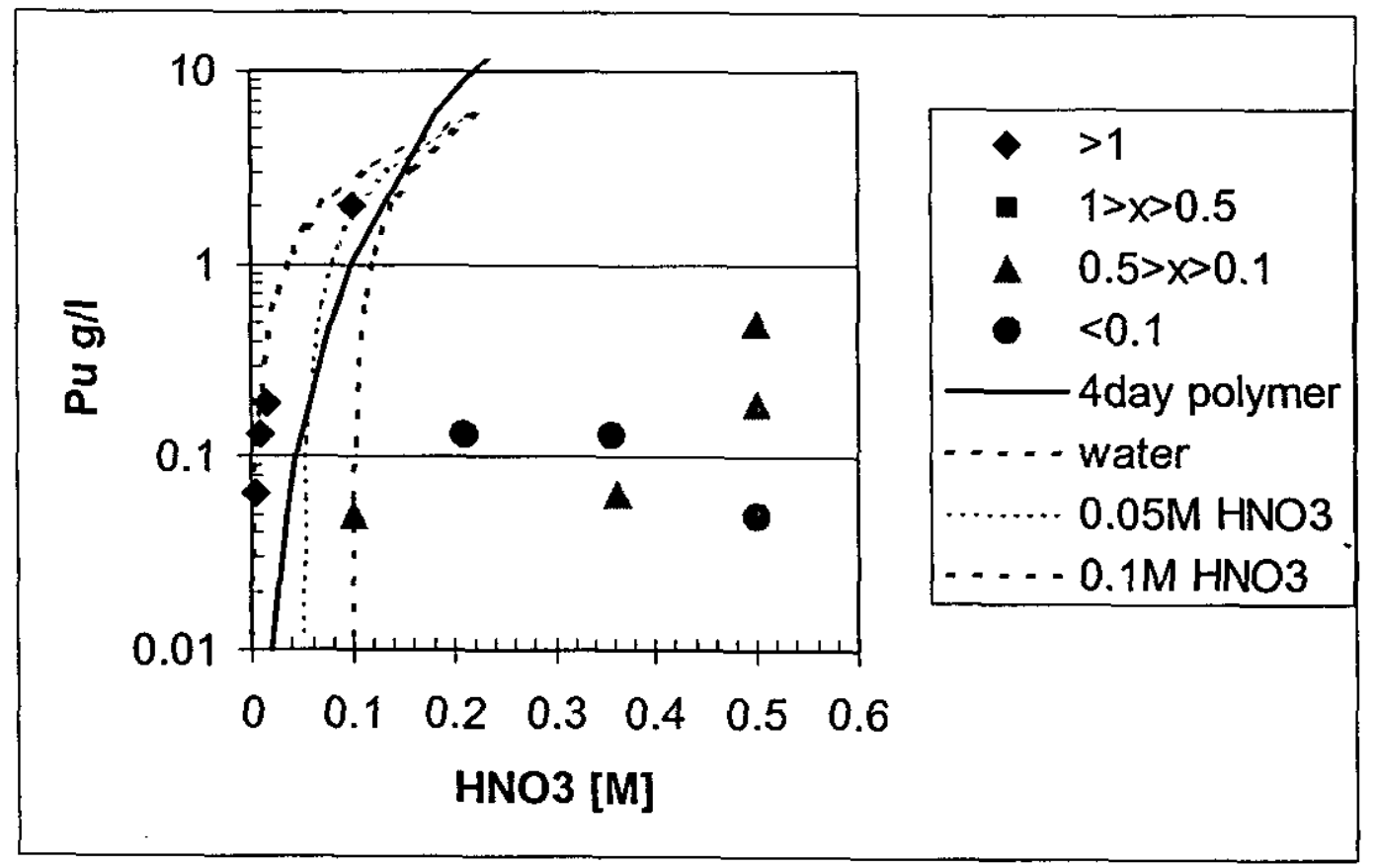

Figure 5. Pu adsorption on $304 \mathrm{~L}$ stainless steel in $\mu \mathrm{g} / \mathrm{cm}^{2}$. Adsorption values are for one week immersion. Additional literature data is at $0.5 \mathrm{M} \mathrm{HNO}_{3}$ and at $2 \mathrm{~g} / \mathrm{l} \mathrm{Pu} .^{2,3}$ Solid line represents the four day polymerization line reported previously ${ }^{1}$ and the dashed lines are dilutions of $6 \mathrm{~g} / \mathrm{Pu} 0.22 \mathrm{M} \mathrm{HNO}_{3}$ with the solution acidities given.

with $>1 \mu \mathrm{g} / \mathrm{cm}^{2}$ are only present to the left of the polymerization line in the polymer region. To the right of the polymerization line, in the non-polymer region, far less adsorption occurs.

The fact that the adsorption of polymer comes to an equilibrium saturation value suggests that its adsorption is much like Pu adsorption on glass and platinum. ${ }^{3,6,9}$ Adherence would be due to initial production of $\mathrm{Pu}(\mathrm{OH})^{3+}$ and other positively charged plutonium hydrolysis species, including polymer. Less and less $\mathrm{Pu}$ would adsorb as the Pu species cover the negatively charged steel producing a positively charged layer which would repel additional adsorption. Additionally, as the size increases and charge decreases on the polymer, less polymer would be expected to adhere. If aged polymer is used, one could expect less $\mathrm{Pu}$ to adhere than non-aged since the aged polymer is larger and has a lower positive charge. A zero point charge, where the charge of the covered steel surface becomes the same as the polymer charge, may be reached so that the polymer is not adsorbed anymore on the steel. The largest sized polymer may even fall out of solution or not be able to adhere to the surface.

Realistically, in industrial-sized processes, the adsorption will be due to the production of fresh polymer, produced accidentally, which will adhere to tank surfaces that are non-polished. The unpolished value of 11 $\mu \mathrm{g} / \mathrm{cm}^{2}$ for pure polymer should be used to calculate how much Pu polymer adsorbs in a stainless steel tank even though some of our initial oxidized steel values may be higher. The equilibrium values are more realistic for the tanks used on site due to the amount of time a solution stays in a tank. The initial adsorption values will either be raised or lowered to equilibrium values depending on the acidity of the 
solution in the tank, its Pu concentration, and how long the situation persists. Thus, although the nonequilibrium values could be used for safety purposes the largest equilibrium amount, $11 \mu \mathrm{g} / \mathrm{cm}^{2}$, should be used as the expected adsorbance of Pu polymer. The amount of Pu adsorbed was previously calculated with this value' for a $14,000 \mathrm{~L}$ tank to be $6.8 \mathrm{~g}$, which is not a significant safety problem.

Although it would be useful to run an experiment at the plant limit of $6 \mathrm{~g} / 1$ and $0.22 \mathrm{M}$ acid, it is not necessary. Pu polymer adsorption will begin at the point that the Pu acid concentration passes the line of polymerization. The adsorption will be very fast and the amount will correspond to that at the point where the acid concentration passes this line. In these experiments, Pu solutions were produced by diluting 19.7 $\mathrm{g} / 1 \mathrm{Pu}$ down to $0.131 \mathrm{~g} / \mathrm{l}$. This is a 150 fold dilution and would correspond to going from $6 \mathrm{~g} / \mathrm{l}$ to $0.04 \mathrm{~g} / \mathrm{in}$ the plant by diluting with water. To get the same $\mathrm{Pu}$ concentration, the $6 \mathrm{~g} / \mathrm{l}$ plant solution would have to be diluted 46 times. This dilution would correspond to going from an acid concentration of $0.22 \mathrm{M}$ to $4.8 \times 10^{-3} \mathrm{M}$ in the plant. Note from Figure 5 that with this dilution the experiments are only slightly above the acid amount expected when a dilution with water of the plant limit $6 \mathrm{~g} / 1 \mathrm{Pu}$ in $0.22 \mathrm{M}$ acid solution is . made. As more Pu would adhere at lower acid concentrations this suggests that the plant tanks would have more Pu adsorbed. However, the plant is usually run at a higher acid concentration, for example $0.4 \mathrm{M}$, and at a lower Pu concentration than its limits. With a $0.4 \mathrm{M}$ acid solution diluted 45 times, the experimental acid concentrations are the same and one would expect the same amount of polymerization and adherence to the steel.

The dilution of a solution of $6 \mathrm{~g} / \mathrm{l} \mathrm{Pu}$ in $0.22 \mathrm{M} \mathrm{HNO}_{3}$ corresponding to $\mathrm{H}$ canyon limits is also shown in Figure 5. Three dilutions are shown, one with water, $0.05 \mathrm{M} \mathrm{HNO}_{3}$, and $0.1 \mathrm{M} \mathrm{HNO}_{3}$. Note the addition of even a small amount of acid in the diluting water is helpful in reducing the amount of Pu that adsorbs since it reduces the amount of area or time that the solution is in the region where polymer is produced. As pointed out in WSRC-TR-99-00008 1 this increases the stability of the solution and lowers the amount of polymer produced due to a concentration gradient, thus decreasing adsorption.

\section{Buildup}

The $\mathrm{Pu}$ adsorption values determined in the non-continuous case follow irreversible desorption. Unlike, cerium and promethium, ${ }^{10} \mathrm{Pu}$ at high acid concentrations was not fully desorbed from the stainless steel in Pu solutions of $5 \mathrm{M} \mathrm{HNO}_{3}$. At $0.35 \mathrm{M} \mathrm{HNO}_{3}$, the data reveal only a small difference of $0.077 \mu \mathrm{g} / \mathrm{cm}^{2}$ between the continuously immersed and the non-continuously immersed case at $0.131 \mathrm{~g} / \mathrm{l} \mathrm{Pu}$. At low acid concentrations the irreversibility became greater but not nearly as large as seen in the literature. The difference on average was only $2 \mu \mathrm{g} / \mathrm{cm}^{2}$ for the low acid case for the same concentration of $\mathrm{Pu}$.

The experimental adsorption values obtained for non-continuous immersion do not seem to agree well with the literature values. ${ }^{2,8,10}$ In the literature, buildup was substantial for both chemical analogues and $\mathrm{Pu}$. The measured adsorption data only increased slightly with non-continuous immersion. The difference is due to experimental technique and the fact that buildup occurs only if there is not enough time for the steel surface to come into equilibrium with the solution. Belloni et al., ${ }^{10}$ attribute this to the destruction of the double layer upon drying which needs to be reestablished before equilibrium can be attained. In the case of $\mathrm{Pu}$ adsorption on stainless steel, Sokhina et al., ${ }^{2}$ removed, dried, and immersed a steel coupon in fresh Pu solution at least 14 times in a week (twice a day), producing a total of 175 drying operations for the three temperatures and four acidities tested. This frequency is much shorter than the equilibrium time of a week that they report for constant immersion of a coupon. Even with such frequency, Pu built up after a week to only $4 \mu \mathrm{g} / \mathrm{cm}^{2}$ on stainless steel in the worst case and the buildup was tapering off. The removal frequency in the experiments here is half of theirs, which allows the equilibrium between the solution and the surface to be more closely attained. Therefore, data obtained should be closer to an equilibrium adsorption value 
and less than non-equilibrium values determined at the same acid and Pu concentration. The highest noncontinuous adsorption value obtained was $7 \mu \mathrm{g} / \mathrm{cm}^{2}$ with $0.131 \mathrm{~g} / \mathrm{Pu}$.

Suprisingly, the relative slowness of large tank filling and batch type operation will reduce the amount of buildup. The fastest tank fill time is on the order of two hours, thus a fill and empty operation will take at least 4 hours. Additionally, retention times may be shifts. The longer duration times allow tank walls to come to equilibrium with the solutions so subsequent filling operations should not build up $\mathrm{Pu}$ as fast. Refilling a tank with a solution lower in Pu concentration but at the same acid content will desorb Pu to some percent depending on the acid concentration. Refilling a tank with a higher Pu concentration and the same acid content should adsorb more Pu to the tank. Additionally, having acid concentrations greater than $0.1 \mathrm{M}$ will remove a percentage of adsorbed $\mathrm{Pu}$. The percentage removed increases to $80 \%$ at $5 \mathrm{M}$.

However, at $\mathrm{pH}$ 's above $2\left(<0.01 \mathrm{M} \mathrm{HNO}_{3}\right)$, adsorbed $\mathrm{Pu}$ is not removed and may lead to further deposition. An amount determined ${ }^{5}$ after 175 drying operations at $95^{\circ} \mathrm{C}$ was found to be $4 \mu \mathrm{g} / \mathrm{cm}^{2}$ for a solution of 0.05 $\mathrm{g} / \mathrm{L} \mathrm{Pu}$ in $0.1 \mathrm{M} \mathrm{HNO}_{3}$. Less adsorption was found at higher acid concentrations and lower temperatures.

If an accidental addition of water into a tank containing Pu occurs, the amount of Pu polymer adsorbed would be expected to depend on the tank fill rate, the mixing rate, and the settling rate. If the fill rate is fast, the lower acid concentration will be reached faster. Since lower acid concentrations do not remove adsorbed $\mathrm{Pu}$ well, the amount adsorbed will be larger than the absorption value expected at equilibrium for that $\mathrm{Pu}$ and acid concentration. If the addition is slow, the amount that adsorbs will be closer to the equilibrium value since the Pu surfaces will have time to reach equilibrium. Rinsing with a higher concentration of acid will remove the adsorbed Pu but it is harder to remove the Pu if it adhered to the tank as polymer than as $\mathrm{Pu}(\mathrm{IV})$. In both cases, the amount adsorbed to the tank will be limited to at most the calculated $6.8 \mathrm{~g}$. If more Pu is in the tank at the time of the addition it will either remain in solution as $\mathrm{Pu}(\mathrm{IV})$ polymer and other $\mathrm{Pu}$ species, precipitate as $\mathrm{Pu}(\mathrm{IV})$ hydroxide, or settle as $\mathrm{Pu}(\mathrm{IV}$ ) polymer. These cases should be immediately responded to as recommended in WSRC-TR-99-00008. '

\section{Conclusions}

The experiments so far have generally confirmed much of what is reported in the literature on adsorption of $\mathrm{Pu}$. Specifically, adsorption of $\mathrm{Pu}$ on stainless steel increases with increased concentration of $\mathrm{Pu}$ in solution, decreased acid concentration, and increased time of contact with the Pu solution. The amount adsorbed was found to come to a limiting value after 5 to 7 days. The amount of Pu which adsorbs on stainless steel is almost an order of magnitude more for a polymer solution than that from a solution with the same concentration of $\mathrm{Pu}(\mathrm{IV})$. $\mathrm{Pu}$ adsorbed on stainless steel is easier to remove when it adheres as $\mathrm{Pu}$ (IV) than if it is adsorbed as polymer. Adsorption values were small varying from $0.5 \mu \mathrm{g} / \mathrm{cm}^{2}$ for a 0.5 $\mathrm{g} / 1 \mathrm{Pu} 0.5 \mathrm{M} \mathrm{HNO}_{3}$ solution to $11 \mu \mathrm{g} / \mathrm{cm}^{2}$ for a $1-3 \mathrm{~g} / 1 \mathrm{Pu} 0.1 \mathrm{M} \mathrm{HNO}_{3}$ solution. Pu polymer adsorption is expected to attain an equilibrium amount on the side of a tank depending on solution acidity and $\mathrm{Pu}$ concentration. This value is not expected to be much larger than $11 \mu \mathrm{g} / \mathrm{cm}^{2}$ which deposits less than $10 \mathrm{~g}$ of $\mathrm{Pu}$ on the surface of a 14,000L tank. Buildup is expected to be small on repeated tank fillings as it is an equilibrium process and tank retention time is long. From this we conclude that adsorption on a tank wall is not to be a safety concern. However, if polymer is accidentally produced in a tank it should be dealt with immediately as in WSRC-TR-99-00008. ${ }^{1}$ 


\section{References}

1) WSRC-TR-99-00008 "Technical Basis for Safe Operations with Pu-239 Polymer in NMS\&S Operating Facilities(F \& H Areas)"1999

2) "Actinoid sorption from Nitric Acid onto Stainless Steel. 1. Plutonium Sorption and Deposition" L.P. Sokhina, L.V. Goncharuk, and S.I. Rovnyi, Soviet Radiochemistry Vol.29, pp.622-624 (1988).

3) "Investigation of the State of Pu(IV) in Dilute Nitric Acid", V.I. Grebenshchikova and . P. Davydov, Soviet Radiochemistry, Vol.3, pp.51-60 (1961).

4) "Adsorption of Plutonium, Neptunium, and Uranium on Stainless Steel from Nitric Acid", L.P. Sokhina, L.V. Goncharuk, and M.G. Nesmirnyi, Soviet Radiochemistry, Vol.31, pp.57-60 (1989).

5) "The Preparation and Properties of Some Plutonium Compounds. Part V. Colloidal Quadrivalent Plutonium", D.W. Ockenden and G.A. Welch, J.Chem.Soc., pp.3358-3363 (1956).

6) "Adsorption of $\mathrm{Pu}(\mathrm{IV})$ on Polished Platinum" A.G. Samartseva, Soviet Radiochemistry Vol.4, pp.463. $467(1961)$.

7) 'No.38-Recherches sur L'Adsorption des Radioéléments en Solution, I. Adsorption de $\mathrm{Pu}^{\mathrm{IV}}$ en Milieu Sulfurique", M. Haissinsky and Y. Laflamme, J. Chim. Phys. 55, p. 510 (1958).

8) "No 85-Recherches sur L'Adsorption des Radioéléments en Solution, I. Adsorption de Pu en Milieu Nitrique", M. Haissinsky and Y. Paiss, J. Chim. Phys. 56, p. 915 (1959).

9) "Adsorption of Pu(IV) on Glass and Quartz" A.G. Samartseva, Soviet Radiochemistry Vol.4, pp.572578 (1962).

10) "On the Adsorption of Some Fission Products on Various Surfaces" J. Belloni, M. Haissinsky, and H.N. Salama, J. Chem. Phys. pp.881-887,(1959).

11) "On the Particle Size Distribution of Hydrolyzed Plutonium(IV) Polymer", F.Ichikawa, and T. Sato, J. Radio.Anal. \& Nucl. Chem., Vol.84, pp.269-275 (1984).

12) WSRC-NB-98-00289, "Pu Polymer" Opened 12/7/98 


\section{Appendix}

Tables 1-6 experimental data and adsorptions. Samples ending in a letter correspond to second or third removal steps.

\begin{tabular}{|c|c|c|c|c|}
\hline exp. 1 & 1 day & 3rd day & 7th day & 8th day \\
\hline $1 \mathrm{a} 1$ & $3.33 \mathrm{e}+04$ & $5.00 \mathrm{e}+04$ & $2.40 \mathrm{e}+06$ & $1.35 \mathrm{e}+06$ \\
\hline $1 \mathrm{a} 1 \mathrm{a}$ & $<3.11 \mathrm{e}+03^{\mathrm{LOD}}$ & --- & --- & - \\
\hline & & & & \\
\hline $1 \mathrm{~b} 1$ & $1.73 \mathrm{e}+04$ & $1.52 \mathrm{e}+04$ & $5.63 \mathrm{e}+05$ & $4.13 \mathrm{e}+05$ \\
\hline $1 \mathrm{bla}$ & $<3.11 \mathrm{e}+03^{\mathrm{LOD}}$ & --- & -- & - \\
\hline & & & & \\
\hline $1 \mathrm{c} 1$ & $<3.11 \mathrm{e}+03^{\mathrm{LOD}}$ & $<3.44 \mathrm{e}+03^{\mathrm{LOD}}$ & $<2.85 \mathrm{e}+01^{\mathrm{LOD}}$ & $<2.85 \mathrm{e}+01^{\mathrm{LOD}}$ \\
\hline $1 \mathrm{cla}$ & - & --- & - & - \\
\hline & & & & \\
\hline
\end{tabular}

Limit of Detection (LOD)

\begin{tabular}{|c|c|c|c|c|l|l|}
\hline $\begin{array}{c}\text { beaker } \\
\text { exp. 1 }\end{array}$ & $\begin{array}{c}\text { 1st } \\
\text { day }\end{array}$ & $\begin{array}{c}\text { 3rd } \\
\text { day* }\end{array}$ & $\begin{array}{c}\text { 7th } \\
\text { day* }\end{array}$ & $\begin{array}{c}8 \text { th } \\
\text { day* }\end{array}$ & \multicolumn{1}{|c|}{ Pu g/l } & [acid] M \\
\hline A & 1.8 & 2.8 & 130 & 75 & 0.154 & 0.69 \\
\hline & & & & & & \\
\hline$B$ & 0.96 & 0.84 & 31 & 23 & 0.154 & 0.69 \\
\hline & & & & & & \\
\hline $\mathrm{C}$ & $<0.17$ & $<0.17$ & -0.00 & $\sim 0.00$ & 0.0 & $\mathrm{H}_{2} \mathrm{O}$ \\
\hline
\end{tabular}

Table 1. Determined values of adsorption from experiment 1 started 2/9/99. Top shows raw data of alpha counts in (disintegrations per minute per $\mathrm{ml}$ ) $\mathrm{dpm} / \mathrm{ml}$ for each sample taken. Bottom shows $\mathrm{Pu}$ adsorption on stainless steel in $\mu \mathrm{g} / \mathrm{cm}^{2}$, which was determined for the experiment. Beaker $\mathrm{C}$ contained deionized water as a blank to check for cross contamination. * Evaporation has taken place.

\begin{tabular}{|c|c|c|c|c|}
\hline exp. 2 & 1 day & 5 th day & 7 th day & 8 th day \\
\hline $2 \mathrm{a} 1$ & $2.41 \mathrm{e}+04$ & $4.14 \mathrm{e}+04$ & $6.80 \mathrm{e}+04$ & $5.17 \mathrm{e}+04$ \\
\hline $2 \mathrm{a} 1 \mathrm{a}$ & $1.27 \mathrm{e}+02$ & --- & $-\cdots$ & $-\cdots$ \\
\hline & & & & \\
\hline $2 \mathrm{~b} 1$ & $1.69 \mathrm{e}+04$ & $8.67 \mathrm{e}+03$ & $<3.06 \mathrm{e}+03^{\text {LOD }}$ & $<3.06 \mathrm{e}+03^{\text {LOD }}$ \\
\hline $2 \mathrm{bla}$ & $1.18 \mathrm{e}+03$ & --- & $-\cdots$ & $-\cdots$ \\
\hline & & & & \\
\hline
\end{tabular}

Limit of Detection (LOD)

\begin{tabular}{|c|c|c|c|c|c|c|}
\hline $\begin{array}{c}\text { beaker } \\
\text { exp.2 }\end{array}$ & $\begin{array}{c}\text { 1st } \\
\text { day }\end{array}$ & $\begin{array}{c}\text { 5th } \\
\text { day }\end{array}$ & $\begin{array}{c}\text { 7th } \\
\text { day }\end{array}$ & $\begin{array}{c}\text { 8th } \\
\text { day }\end{array}$ & Pu g/l & [acid] $M$ \\
\hline A & 1.3 & 2.3 & 3.8 & 2.9 & 0.191 & 0.015 \\
\hline & & & & & & \\
\hline B & 1.0 & 0.48 & $<0.17$ & $<0.17$ & 0.191 & 5.0 \\
\hline
\end{tabular}

Table 2. Determined values of adsorption from experiment 2 started 3/3/99. Top shows raw data of alpha counts in (disintegrations per minute per $\mathrm{ml}$ ) $\mathrm{dpm} / \mathrm{ml}$ for each sample taken. Bottom shows $\mathrm{Pu}$ adsorption on stainless steel in $\mu \mathrm{g} / \mathrm{cm}^{2}$, which was determined for the experiment. 
WSRC-TR-99-00210

\begin{tabular}{|c|c|c|c|c|}
\hline exp. 3 & 1 day & 5 th day & 7 th day & 7 th day \\
\hline $3 \mathrm{dl}$ & $1.03 \mathrm{e}+03$ & $6.48 \mathrm{e}+03$ & $2.53 \mathrm{e}+03$ & $1.66 \mathrm{e}+03$ \\
\hline $3 \mathrm{~d} 1 \mathrm{a}$ & $1.38 \mathrm{e}+01$ & $6.48 \mathrm{e}+01^{\text {LOD }}$ & $6.48 \mathrm{e}+01^{\text {LOD }}$ & $\cdots$ \\
\hline $3 \mathrm{~d} 1 \mathrm{~b}$ & $8.78 \mathrm{e}+00$ & $\cdots$ & $\cdots$ & $\cdots$ \\
\hline & & & & \\
\hline $3 \mathrm{e} 1$ & $7.69 \mathrm{e}+03$ & $2.05 \mathrm{e}+04$ & $1.70 \mathrm{e}+04$ & $2.50 \mathrm{e}+04$ \\
\hline $3 \mathrm{e} 1 \mathrm{a}$ & $4.01 \mathrm{e}+02$ & $6.48 \mathrm{e}+01^{\text {LOD }}$ & $6.48 \mathrm{e}+01^{\mathrm{LOD}}$ & $\cdots$ \\
\hline $3 \mathrm{e} 1 \mathrm{~b}$ & $6.21 \mathrm{e}+00^{\mathrm{LOD}}$ & ---- & $\cdots$ & $\cdots$ \\
\hline & & & & \\
\hline
\end{tabular}

Limit of Detection (LOD)

\begin{tabular}{|c|c|c|c|c|l|l|}
\hline $\begin{array}{c}\text { beaker } \\
\text { exp. 3 }\end{array}$ & $\begin{array}{c}1 \text { st } \\
\text { day }\end{array}$ & $\begin{array}{c}5 \text { th } \\
\text { day }\end{array}$ & $\begin{array}{c}\text { 7th } \\
\text { day }\end{array}$ & $\begin{array}{c}\text { 8th } \\
\text { day }\end{array}$ & \multicolumn{1}{|c|}{ Pu g/1 } & [acid] M \\
\hline $\mathrm{D}$ & 0.058 & 0.36 & 0.14 & 0.092 & $6.56 \mathrm{e}-2$ & 0.35 \\
\hline & & & & & & \\
\hline $\mathrm{E}$ & 0.45 & 1.1 & 0.94 & 1.4 & $6.56 \mathrm{e}-2$ & $4.4 \mathrm{e}-3$ \\
\hline
\end{tabular}

Table 3. Determined values of adsorption from experiment 3 started 4/6/99. Top shows raw data of alpha counts in (disintegrations per minute per $\mathrm{ml}$ ) $\mathrm{dpm} / \mathrm{ml}$ for each sample taken. Bottom shows $\mathrm{Pu}$ adsorption on stainless steel in $\mu \mathrm{g} / \mathrm{cm}^{2}$, which was determined for the experiment.

\begin{tabular}{|c|c|c|c|c|}
\hline exp. 4 & 1 day & 5 th day & 6 th day & 7 th day \\
\hline $4 \mathrm{a} 1$ & $4.80 \mathrm{e}+04$ & $1.94 \mathrm{e}+05$ & $1.39 \mathrm{e}+05$ & $5.45 \mathrm{e}+04$ \\
\hline $4 \mathrm{a} 1 \mathrm{a}$ & $7.71 \mathrm{e}+01$ & $4.76 \mathrm{e}+02$ & $1.96 \mathrm{e}+01$ & $4.36 \mathrm{e}+01$ \\
\hline & & & & \\
\hline $4 \mathrm{~b} 1$ & $7.54 \mathrm{e}+02$ & $1.80 \mathrm{e}+02$ & $4.58 \mathrm{e}+02$ & $7.35 \mathrm{e}+02$ \\
\hline $4 \mathrm{~b} 1 \mathrm{a}$ & $3.58 \mathrm{e}+01$ & $1.23 \mathrm{e}+01^{L 0 D}$ & $1.33 \mathrm{e}+02$ & $1.93 \mathrm{e}+01$ \\
\hline & & & & $1.76 \mathrm{e}+03$ \\
\hline $4 \mathrm{c} 1$ & $1.37 \mathrm{e}+02$ & $1.06 \mathrm{e}+02$ & $4.54 \mathrm{e}+02$ & $3.77 \mathrm{e}+02$ \\
\hline $4 \mathrm{c} 1 \mathrm{a}$ & $1.12 \mathrm{e}+01$ & $1.23 \mathrm{e}+01^{\text {LOD }}$ & $1.56 \mathrm{e}+01$ & \\
\hline & & & & \\
\hline
\end{tabular}

Limit of Detection (LOD)

\begin{tabular}{|c|c|c|c|c|l|l|}
\hline $\begin{array}{c}\text { beaker } \\
\text { exp. 4 }\end{array}$ & $\begin{array}{c}1 \text { st } \\
\text { day }\end{array}$ & $\begin{array}{c}\text { 5th } \\
\text { day }\end{array}$ & $\begin{array}{c}\text { 6th } \\
\text { day }\end{array}$ & $\begin{array}{c}7 \text { th } \\
\text { day }\end{array}$ & \multicolumn{1}{|c|}{ Pu g/1 } & [acid] M \\
\hline A & 2.7 & 11 & 7.7 & 3.0 & 0.131 & $8.9 \mathrm{e}-3$ \\
\hline & & & & & & \\
\hline B & 0.044 & 0.011 & 0.033 & 0.042 & 0.131 & 0.36 \\
\hline & & & & & & \\
\hline C & 0.008 & 0.007 & 0.026 & 0.12 & 0.131 (lifted) & 0.36 \\
\hline
\end{tabular}

Table 4. Determined values of adsorption from experiment 4 started 4/15/99. Top shows raw data of alpha counts in (disintegrations per minute per $\mathrm{ml}$ ) $\mathrm{dpm} / \mathrm{ml}$ for each sample taken. Bottom shows $\mathrm{Pu}$ adsorption on stainless steel in $\mu \mathrm{g} / \mathrm{cm}^{2}$, which was determined for the experiment. 
WSRC-TR-99-00210

\begin{tabular}{|c|c|c|c|c|}
\hline exp. 5 & 1 day & 4th day & 6 th day & 7 th day \\
\hline $5 \mathrm{a} 1$ & $2.34 \mathrm{e}+02$ & $7.69 \mathrm{e}+01$ & $1.28 \mathrm{e}+02$ & $8.00 \mathrm{e}+01$ \\
\hline $5 \mathrm{a} 1 \mathrm{a}$ & $2.18 \mathrm{e}+01$ & $8.16 \mathrm{e}+01$ & $1.21 \mathrm{e}+02^{\text {LOD }}$ & $2.27 \mathrm{e}+01$ \\
\hline & & & & \\
\hline $5 \mathrm{bl}$ & $1.34 \mathrm{e}+05$ & $1.01 \mathrm{e}+05$ & $2.75 \mathrm{e}+05$ & $1.26 \mathrm{e}+05$ \\
\hline $5 \mathrm{~b} 1 \mathrm{a}$ & $8.79 \mathrm{e}+02$ & $1.02 \mathrm{e}+02$ & $4.60 \mathrm{e}+02$ & $1.25 \mathrm{e}+02$ \\
\hline & & & & \\
\hline $5 \mathrm{c} 1$ & $1.08 \mathrm{e}+05$ & $3.05 \mathrm{e}+04$ & $1.31 \mathrm{e}+05$ & $1.27 \mathrm{e}+05$ \\
\hline $5 \mathrm{c} 1 \mathrm{a}$ & $1.64 \mathrm{e}+02$ & $6.53 \mathrm{e}+01$ & $8.33 \mathrm{e}+01$ & $1.25 \mathrm{e}+02$ \\
\hline & & & & \\
\hline
\end{tabular}

Limit of Detection (LOD)

\begin{tabular}{|c|c|c|c|c|l|l|}
\hline $\begin{array}{c}\text { beaker } \\
\text { exp. 5 }\end{array}$ & $\begin{array}{c}\text { 1st } \\
\text { day }\end{array}$ & $\begin{array}{c}\text { 4th } \\
\text { day }\end{array}$ & $\begin{array}{c}6 \text { th } \\
\text { day }\end{array}$ & $\begin{array}{c}7 \text { th } \\
\text { day }\end{array}$ & Pu g/1 & [acid] M \\
\hline A & 0.014 & 0.009 & 0.08 & 0.006 & 0.131 & 5.0 \\
\hline & & & & & & \\
\hline B & 7.5 & 5.7 & 15.0 & 7.0 & 0.131 & $8.9 \mathrm{e}-3$ \\
\hline & & & & & & \\
\hline C & 6.0 & 1.697 & 7.3 & 7.1 & 0.131 (lifted) & $8.9 \mathrm{e}-3$ \\
\hline
\end{tabular}

Table 5. Determined values of adsorption from experiment 5 started 4/23/99. Top shows raw data of alpha counts in (disintegrations per minute per $\mathrm{ml}$ ) $\mathrm{dpm} / \mathrm{ml}$ for each sample taken. Bottom shows $\mathrm{Pu}$ adsorption on stainless steel in $\mu \mathrm{g} / \mathrm{cm}^{2}$, which was determined for the experiment.

\begin{tabular}{|c|c|c|c|c|}
\hline exp. 6 & 1 day & 3rd day & 6th day & 7th day \\
\hline $6 \mathrm{al}$ & $5.64 \mathrm{e}+02$ & $9.76 \mathrm{e}+02$ & $8.87 \mathrm{e}+02$ & $1.31 \mathrm{e}+03$ \\
\hline $6 \mathrm{ala}$ & $2.00 \mathrm{e}+01$ & $2.49 \mathrm{e}+01$ & $1.12 \mathrm{e}+02$ & $1.01 \mathrm{e}+02$ \\
\hline & & & & \\
\hline $6 \mathrm{bl}$ & $5.59 \mathrm{e}+03$ & lost sample & $3.17 \mathrm{e}+03$ & $2.11 \mathrm{e}+03$ \\
\hline $6 \mathrm{bla}$ & $1.33 \mathrm{e}+02$ & lost sample & $1.72 \mathrm{e}+02$ & $1.46 \mathrm{e}+02$ \\
\hline & & & & \\
\hline $6 \mathrm{cl}$ & $6.56 \mathrm{e}+01$ & lost sample & $9.67 \mathrm{e}+01$ & $1.40 \mathrm{e}+03$ \\
\hline $6 \mathrm{cla}$ & $1.64 \mathrm{e}+01$ & lost sample & $3.31 \mathrm{e}+01$ & $9.31 \mathrm{e}+02$ \\
\hline & & & & \\
\hline
\end{tabular}

\begin{tabular}{|c|c|c|c|c|c|c|}
\hline $\begin{array}{c}\text { beaker } \\
\text { exp. 6 }\end{array}$ & $\begin{array}{c}\text { 1st } \\
\text { day }\end{array}$ & $\begin{array}{c}\text { 3rd } \\
\text { day }\end{array}$ & $\begin{array}{c}\text { 6th } \\
\text { day }\end{array}$ & $\begin{array}{c}7 \text { th } \\
\text { day }\end{array}$ & Pu g/1 & [acid] M \\
\hline A & 0.032 & 0.056 & 0.055 & 0.078 & 0.131 & 0.21 \\
\hline & & & & & & \\
\hline B & 0.32 & $\ldots$ & 0.19 & 0.13 & 0.131 (lifted) & $1.9 \mathrm{e}-2$ \\
\hline & & & & & & \\
\hline C & 0.005 & $-\cdots$ & 0.007 & 0.083 & 0.154 (lifted) & 0.69 \\
\hline
\end{tabular}

Table 6. Determined values of adsorption from experiment 6 started 5/4/99. Top shows raw data of alpha counts in (disintegrations per minute per $\mathrm{ml}$ ) dpm/ml for each sample taken. Bottom shows $\mathrm{Pu}$ adsorption on stainless steel in $\mu \mathrm{g} / \mathrm{cm}^{2}$, which was determined for the experiment. 